\title{
MODELING THE CONTRIBUTION OF DISTANCE EDUCATION TO STUDENTS' PREPARATION FOR THE PROFESSIONS
}

\author{
Dr. Mustafa CAVUS \\ ORCID: 0000-0002-6172-5449 \\ Department of Statistics, Eskisehir Technical University \\ Eskisehir, TURKEY
}

Dr. Betul KAN KILINC

ORCID: 0000-002-3746-2327

Department of Statistics, Eskisehir Technical University

Eskisehir, TURKEY

Dr. Berna YAZICI

ORCID: 0000-0001-9843-7355

Department of Statistics, Eskisehir Technical University

Eskisehir, TURKEY

Dr. Seda TEKELI

ORCID: 0000-0003-1839-8291

Department of Labor Economy and Industrial Relations, Anadolu University

Eskisehir, TURKEY

Dr. Guler GUNSOY

ORCID: 0000-0002-0104-9784

Department of Economy, Anadolu University Eskisehir, TURKEY

Dr. Bulent GUNSOY

ORCID: 0000-0001-6370-189X

Department of Economy, Anadolu University

Eskisehir, TURKEY

Dr. Caglar KARADUMAN

ORCID: 0000-0002-4956-6684

Department of Economy, Anadolu University

Eskisehir, TURKEY

Received: 08/05/2019 Accepted: 26/08/2019

\begin{abstract}
There is an increasing interest in predicting the contribution level of open and distance learning to students' career, in order to perceive the pathway for higher quality standards. For this purpose, Anadolu University Faculty of Open Education, which can be considered a leader in its field, to learners' professions and their career goals, organized a research project in which a questionnaire was conducted involving approximately 17,000 associate and undergraduate students to build a database of responses. The data was used to determine the contribution level of the open education programs. The five ordered-level contributions were recorded to a response variable. Demographical, educational and economic variables were successfully used in mapping the categorical responses using the ordinal logistic regression analysis method (OLR). The results, unlike other studies, indicate that there is a positive relationship between family size and the contribution level of distance education on students' preparation for the professions. In a novel way, the socioeconomic level of the students is considered in the OLR model as an economic factor. As a consequence, the students with moderate and higher socioeconomic levels demonstrated superior levels of contribution.
\end{abstract}


Keywords: Distance education, life goals, profession, ordinal logistic regression.

\section{INTRODUCTION}

In the field of economics of education, much of the literature points out that the education system of a country is directly related to its labor market. The quality and scope of the education are of great importance considering the demand in a labor market and the structural adjustment capability. In addition, education provides people with the ability to improve themselves and their ability to enjoy equal opportunities. All these achievements increase the possibility of acquiring a profession and forging ahead in a profession (Allmendiger, 1989; Boccanfuso, Larouche, \& Trandafir, 2015).

Educational institutions, especially for higher education, are of the greatest importance when it comes to social, economic, technological, scientific and cultural change. Organizations for higher education help to improve the quality of personal and social life by their valuable contributions and services. These organizations also provide people with both technical and professional knowledge, so that they are able to break into the upper levels of society and, thereby, dynamize the society (Scott, 2002).

Increasing and accelerating technological developments with globalization have brought many changes in social, economic and environmental areas. These changes; while sometimes causing people to face some difficulties; also brought new opportunities for humanity to progress. However, education is perhaps the only way to evaluate and use opportunities (OECD, 2018). Today's children who are new to education, are going to become young people after ten years and adults after fifty years. In this context, schools prepare children for working life; which consists of continuous changes that is expected to take place. Thus, education should also be continuous and it should continue after a student completes the formal school period. Therefore, the demand for a better and more inclusive open and distance education system is expected to increase.

Different student profiles, rapid changes in education technologies and a contemporary understanding of professional developments entail individuals planning to enter the labor market or to stay there to update their knowledge, abilities, and competence. Therefore, distance education is an important opportunity, especially for individuals with limited access to conventional education.

In this context, education delivered only within educational institutions has remained incapable of determining quality and, therefore, learner satisfaction, attitudes, needs, and experience have become more important. This situation is known as 'educational satisfaction' in the related literature. This transformation has caused universities to investigate how to fulfil the expectations and satisfaction of students and, ultimately, all of society (Sahin \& Shelley, 2008).

The motivation for preferences when choosing college programs differ among students. The main incentives for choosing programs include a fear of not being enrolled on any program, of acquiring a profession, and of securing a future. In this context, many students at some point have to choose programs that may not attract them, and instead choose less enticing ones. In other words, nowadays, the main concerns of a typical student may be seen as enrolling on a college program and graduating from that program with a successful degree. A third important goal may be to realize life expectations. Graduating from a suitable college program may easily be translated into a satisfied society (Sahin \& Shelley, 2008).

Jacobs and Newstead studied 336 psychology students studying at universities in Southern England in 2000. The results of the study show that the knowledge and skills gained by university education have a significant place in the students' motivation to study. In the acquisition of these knowledge and skills, the self-discipline that the university education brings to students plays an effective role (Jacobs \& Newstead, 2000).

The binary logistic regression model is used when possible answers after examining an outcome variable may be either 'yes' or 'no'. However, we are frequently confronted with questions that cannot be answered with a simple yes or'no; a range of possible responses may apply, such as 'unhappy', 'somewhat happy' or 'very happy'. In such cases, the ordinal logistic regression model is used to identify the effect on the level of contribution. Maheswari \& Sudeep Kumar (2010) investigated the contribution of open and distance learning programs on the job performance of veterinary practitioners. They analyzed the ordinal outcome as a contribution of the program through descriptive statistics. However, there have been numerous studies in distance education research to model the effects on a variable. Sahin \& Shelley (2008) used Structural 
Equation Analysis to test the relationships among computer knowledge, flexibility of distance education, usefulness of distance education, and distance education satisfaction. Kuo, Walker, Belland, \& Schroder (2013) intended to investigate the degree of student satisfaction in on-line learning settings using the multiple regression model. Ozturk (2018) used Logistic Regression models to investigate factors affecting enrollment decisions of prospective students of distance education programs. Trehan \& Joshi (2018) built Logistic Regression models to explain choices when adopting on-line open courses in India.

This study concerns a survey that has been conducted in order to model the contribution of distance education to students' preparation for the professions. Firstly, the ordinal logistic regression model is reviewed, after which the participants are introduced. Next, the demographic structure of the students, the OLR models for the data set and the interpretations of the models are given. Finally, the results are discussed in the final section.

\section{ORDINAL LOGISTIC REGRESSION MODEL}

Ordinal logistic regression analysis is an extension of the generalized linear model for ordinal categorical data. In many studies, the variables of interest are ordinal-scaled where the ordering of the categories of the variable is important. For example, happiness can be graded from strongly unhappy to strongly happy. Similarly, diseases can be scaled from least severe to most severe. In this study, the levels of contribution of distance education for the preparation for the professions are graded from 'strongly disagree (1)', 'disagree (2)', 'undecided (3)', 'agree (4)', and 'strongly agree (5)'.

Generally, when the dependent variable is nominal, researchers prefer the logistic regression method to fit the data. However, when the order of the categories of the dependent variable cannot be ignored, then the ordinal logistic regression analysis is usually preferred.

In ordinal logistic regression, the category of interest observes a particular score or less, given in Eq. (1). The odds are of the form:

$Q_{\mathrm{i}}=\operatorname{prob}($ score $\leq i) / \operatorname{prob}($ score $>i)$

or equally $Q_{i}=\operatorname{prob}($ score $\leq i) /(1-\operatorname{prob}($ score $\leq i))$ from complementary property.

The ordinal logic is a linear function of $k$ independent variables given in Eq. (2)

$\log \left(Q_{i}\right)=a_{i}-\left(\beta_{1} X_{1}+\ldots+\beta_{j} X_{j}\right)$

where $i, j=1$ : number of categories-1. Each logit has its intercept and the same coefficient which are used to calculate predicted values. This indicates that the independent variables have the same influence on each logit function.

The probabilities for the individual scores can be calculated by subtraction, using the formula:

$\operatorname{prob}($ score $=i)=\operatorname{prob}($ score $\leq i)-\operatorname{prob}($ score $<i)$

To calculate the cumulative probabilities from the logistic model for each score, Eq. (4) is used:

$$
P_{i}=\operatorname{prob}(\text { score } i)=1 /\left(1+e^{-\left(\alpha_{i}+\beta_{j} X_{j}\right)}\right)
$$

This probability gives the value for the $\mathrm{i}^{\text {th }}$ subject of $X_{i}$ s.

\section{Participants}

The population is defined as students of the Faculty of Open Education, Faculty of Economics and Faculty of Business Administration at Anadolu University in Turkey. $45 \%$ of the students in the study were male and $55 \%$ were female. The demographic structure of the students is summarized in Table 1. 
Table 1. Demographic structure of the students

\begin{tabular}{|c|c|c|c|}
\hline Variables & $\%$ & Variables & $\%$ \\
\hline Gender & & Faculty & \\
\hline Male & 45.4 & Open Education & 81.9 \\
\hline Female & 54.6 & Economics & 8.8 \\
\hline Marital Status & & Business Administration & 9.3 \\
\hline Single & 62.4 & Class & \\
\hline Married & 37.6 & 1 & 24.2 \\
\hline Working Status & & 2 & 29.7 \\
\hline Working & 58.8 & 3 & 17.2 \\
\hline Not working & 41.2 & 4 & 28.9 \\
\hline Income & & Second University Status & \\
\hline $1-1500 \mathrm{TL}$ & 15.9 & Yes & 21.3 \\
\hline 501-1000 TL & 8.8 & No & 78.7 \\
\hline 1001-1500 TL & 19.5 & Mother's Education Level & \\
\hline $1501-2000 \mathrm{TL}$ & 18.5 & Non-literate & 24.6 \\
\hline 2001 TL and more & 37.3 & Compulsory degree & 67.4 \\
\hline Family Income & & High degree & 8 \\
\hline $1000 \mathrm{TL}$ and less & 21.0 & Father's Education Level & \\
\hline $1001-2000 \mathrm{TL}$ & 34.4 & Non-literate & 10.5 \\
\hline 2001-3000 TL & 23.3 & Compulsory degree & 74.8 \\
\hline $3001-4000 \mathrm{TL}$ & 11.2 & High degree & 14.7 \\
\hline 4001 TL and more & 10.1 & Department & \\
\hline Settlement & & Jurisprudence & 9.9 \\
\hline Village & 8.7 & Labor Ec. and Ind. Rel. & 2.7 \\
\hline Town & 31.3 & Theology & 7.3 \\
\hline Province & 60.0 & Economics & 3.2 \\
\hline Socioeconomic Level & & Business Administration & 19.0 \\
\hline Very bad & 9.0 & Public Administration & 13.1 \\
\hline Bad & 19.4 & Public Finance & 3.8 \\
\hline Moderate & 51.0 & Social Services & 5.0 \\
\hline Good & 15.4 & Sociology & 6.2 \\
\hline \multirow[t]{3}{*}{ Very good } & 5.2 & Turk. Lang. and Lit. & 2.3 \\
\hline & & International Relations & 5.0 \\
\hline & & Others (46) & 22.5 \\
\hline
\end{tabular}

The percentage of the students studying a second university education was $21 \%$. Only $8.7 \%$ of the respondents lived in a village, while the others lived in a town or province.

\section{Data Collection and Analysis}

Data was obtained through an on-line questionnaire conducted over approximately one year, between February 2016 to April 2017. The questionnaire was completed by around 17,000 students of the Faculty of Open Education, Faculty of Economics and Faculty of Business Administration at Anadolu University, in order to determine the contribution level of distance education toward students' life goals. In this study, OLR analysis was used, since the dependent variable has five ordered categories; 'strongly disagree', 'disagree', 'undecided', 'agree', 'strongly agree'. The predictor variables are grouped as demographical, educational and economic in the models; hence, three OLR models are considered. MASS package in R is used to construct the OLR model. 


\section{FINDINGS}

The opinions of the students regarding the contribution level of Open Education on preparation for the professions is modeled by OLR. In this section, three OLR models are considered for demographic, educational and economic factors, respectively. Settlement, gender, marital status and number of households of the students are demographic factors which are considered as independent variables, whereas the contribution to the students' preparation for the professions as independent variable (ordered as strongly disagree, disagree, undecided, agree, and strongly agree) in the OLR model. The outputs of the model are shown in Table 2.

The results indicate that four independent variables for all of the categories were statistically significant. Interpretations of the intercepts are not of much interest and are used to predict values. Firstly, the intercept in Eq. (5) is - 0.5952 . Secondly, the reference category for the gender variable is female, which has coefficient of 0.24 . One way to interpret the coefficients for the independent variable is using an odds ratio. The odds ratio in Table 2 for gender is $\exp (0.2481)=1.2816$. In other words, female students who supported the contribution of distance education toward students' professions were 1.28 times greater in number than male students. Similarly, the students who lived in a province supported the contribution of distance education toward students' professions 1.47 times more than the students who lived in a village. The students living with more than five in a household supported the contribution of distance education toward students' professions 2.47 times more than the students living in households of two to four. The interpretation of the odds ratios for the remaining independent variables is straightforward.

Table 2. Outputs of the OLR model for demographic factors

\begin{tabular}{|c|c|c|c|c|c|}
\hline Variables & $\hat{\beta}$ & std. error & $\mathrm{t}$ value & odds ratio & $\mathrm{p}$-value \\
\hline \multicolumn{6}{|l|}{ Dependent } \\
\hline $1 \mid 2$ & -0.5952 & 0.0572 & -1.0413 & 0.5515 & $0^{*}$ \\
\hline $2 \mid 3$ & 0.5972 & 0.0571 & 1.0451 & 1.8171 & $0^{*}$ \\
\hline $3 \mid 4$ & 1.3482 & 0.0581 & 2.3202 & 3.8505 & $0^{*}$ \\
\hline $4 \mid 5$ & 3.3725 & 0.0677 & 4.9780 & 2.9152 & $0^{*}$ \\
\hline \multicolumn{6}{|l|}{ Independent } \\
\hline Gender(female) & 0.2481 & 0.0321 & 7.7344 & 1.2816 & $0^{*}$ \\
\hline Settlement(town) & 0.3355 & 0.0617 & 5.4400 & 1.3987 & $0^{*}$ \\
\hline Settlement(province) & 0.3863 & 0.0585 & 6.6017 & 1.4715 & $0^{*}$ \\
\hline Marital status(married) & 0.1816 & 0.0331 & 5.4789 & 1.1991 & $0^{*}$ \\
\hline Households(2-4) & 0.6996 & 0.1594 & 4.3879 & 2.0129 & $0^{*}$ \\
\hline Households(5+) & 0.8235 & 0.3776 & 2.1807 & 2.2785 & $0.0292^{*}$ \\
\hline
\end{tabular}

Note. ${ }^{*} p<.05$

OLR models for outcomes of the contribution levels are given in Eqs. $(5,6,7,8)$, respectively.

$$
\begin{aligned}
& \log \left(Q_{1}\right)=-0.5952+(0.2481) * \text { Gender }_{\text {female }}+(0.3355) * \text { Site }_{\text {town }}+(0.3863) \\
& * \text { Site }_{\text {province }}+(0.1816) * \text { Marital status } \text { married }+(0.6996) \\
& \text { *Households } \text { H-4 }_{2}+(0.8235) * \text { Households }_{5+} \\
& \log \left(Q_{2}\right)=0.5972+(0.2481) * \text { Gender }_{\text {female }}+(0.3355) * \text { Site }_{\text {town }}+(0.3863) \\
& * \text { Site }_{\text {province }}+(0.1816) * \text { Marital status } s_{\text {married }}+(0.6996) \\
& \text { *Households } s_{2-4}+(0.8235) * \text { Households }_{5+} \\
& \log \left(Q_{3}\right)=1.3482+(0.2481) * \text { Gender }_{\text {female }}+(0.3355) * \text { Site }_{\text {town }}+(0.3863) \\
& * \text { Site }_{\text {province }}+(0.1816) * \text { Marital status } \text { married }+(0.6996) \\
& \text { *Households } s_{2-4}+(0.8235) * \text { Households }_{5+} \\
& \log \left(Q_{4}\right)=3.3725+(0.2481) * \text { Gender }_{\text {female }}+(0.3355) * \text { Site }_{\text {town }}+(0.3863) \\
& * \text { Site }_{\text {province }}+(0.1816) * \text { Marital status } \text { married }+(0.6996) \\
& \text { *Households } s_{2-4}+(0.8235) * \text { Households }_{5+}
\end{aligned}
$$


As can be seen in these equations, the left side of the equation is called logit. This is the logarithm of the odds of a category occuring. The coefficients in each logistic regression model indicate the amount of logit changes on the values of the predictors. Each logit model has its own intercept. For instance, the coefficient $(-0.5952)$ is the intercept (or threshold) of Eq. (5). On the other hand, the remainder of the coefficients, except the intercept term in each equation $(0.5973,1.3482,3.3725$, respectively), means that the effect of the predictor variable is the same for different logit functions and, hence, the model is called proportional odds model.

The calculated predicted probabilities of the model for demographic factors are shown in Table 3.

Table 3. Predicted probabilities of the OLR model for demographic factors

\begin{tabular}{|c|c|c|c|c|c|c|c|c|}
\hline \multirow[b]{2}{*}{ Gender } & \multirow[b]{2}{*}{ Marital Status } & \multirow[b]{2}{*}{ Settlement } & \multirow[b]{2}{*}{ Households } & \multicolumn{5}{|c|}{ Contribution Level } \\
\hline & & & & 1 & 2 & 3 & 4 & 5 \\
\hline \multirow[t]{18}{*}{ Male } & Single & Village & 1 & .355 & .290 & .148 & .174 & .033 \\
\hline & & & $2-4$ & .215 & .259 & .181 & .280 & .065 \\
\hline & & & $5+$ & .195 & .249 & .184 & .300 & .073 \\
\hline & & Town & 1 & .283 & .282 & .168 & .222 & .046 \\
\hline & & & $2-4$ & .164 & .228 & .184 & .335 & .088 \\
\hline & & & $5+$ & .148 & .216 & .183 & .355 & .099 \\
\hline & & Province & 1 & .273 & .280 & .170 & .229 & .048 \\
\hline & & & $2-4$ & .157 & .223 & .184 & .344 & .092 \\
\hline & & & $5+$ & .141 & .210 & .182 & .363 & .103 \\
\hline & Married & Village & $1-2$ & .294 & .284 & .165 & .213 & .043 \\
\hline & & & $3-4$ & .171 & .234 & .185 & .326 & .084 \\
\hline & & & $5+$ & .155 & .221 & .184 & .347 & .094 \\
\hline & & Town & $1-2$ & .229 & .266 & .179 & .266 & .060 \\
\hline & & & $3-4$ & .129 & .199 & .179 & .380 & .113 \\
\hline & & & $5+$ & .116 & .185 & .175 & .398 & .127 \\
\hline & & Province & $1-2$ & .221 & .262 & .180 & .274 & .063 \\
\hline & & & $3-4$ & .123 & .193 & .178 & .387 & .119 \\
\hline & & & $5+$ & .110 & .180 & .173 & .404 & .132 \\
\hline \multirow[t]{18}{*}{ Female } & Single & Village & 1 & .315 & .287 & .159 & .199 & .040 \\
\hline & & & $2-4$ & .186 & .244 & .184 & .310 & .077 \\
\hline & & & $5+$ & .168 & .231 & .184 & .330 & .086 \\
\hline & & Town & 1 & .247 & .273 & .176 & .250 & .054 \\
\hline & & & $2-4$ & .140 & .209 & .182 & .364 & .104 \\
\hline & & & $5+$ & .126 & .196 & .179 & .383 & .116 \\
\hline & & Province & 1 & .238 & .269 & .177 & .258 & .057 \\
\hline & & & $2-4$ & .134 & .204 & .181 & .372 & .109 \\
\hline & & & $5+$ & .121 & .191 & .177 & .391 & .121 \\
\hline & Married & Village & $1-2$ & .258 & .276 & .173 & .241 & .052 \\
\hline & & & $3-4$ & .147 & .215 & .183 & .356 & .099 \\
\hline & & & $5+$ & .132 & .202 & .180 & .375 & .110 \\
\hline & & Town & $1-2$ & .199 & .251 & .183 & .296 & .071 \\
\hline & & & $3-4$ & .110 & .179 & .173 & .405 & .133 \\
\hline & & & $5+$ & .098 & .166 & .167 & .421 & .148 \\
\hline & & Province & $1-2$ & .191 & .246 & .184 & .304 & .074 \\
\hline & & & $3-4$ & .105 & .174 & .170 & .412 & .139 \\
\hline & & & $5+$ & .094 & .161 & .164 & .427 & .155 \\
\hline
\end{tabular}

Note. Contribution levels 1: strongly disagree, 2: disagree, 3: undecided, 4: agree, 5: strongly agree

The predicted probabilities shown in Table 3 are calculated using Eqs. $(5,6,7,8)$. For example, a single male student living in a village strongly disagrees with the probability of $33.5 \%$ on the contribution of distance education toward preparation for the professions. According to predicted probabilities, the contribution of distance education to the preparation for a profession is higher than that of female students. Students living 
in a province stated that their contribution level was higher than for those living in districts and villages, respectively. Single students thought that the level of contribution was higher than for married students. An increase in the numbers per household also increases the contribution for students in preparation for a profession. As a result, students who stated that the contribution level was highest were married women living in provinces. The lowest were single male students living in villages.

The status of the second university, faculty, class, and parental educational levels of the students are educational factors which are considered in the OLR model. The output of the model are shown in Table 4.

Table 4. Outputs of the OLR model for educational factors

\begin{tabular}{|c|c|c|c|c|c|}
\hline Variables & $\hat{\beta}$ & std. error & t value & odds ratio & $\mathrm{p}$-value \\
\hline \multicolumn{6}{|l|}{ Dependent } \\
\hline $1 \mid 2$ & -1.2213 & 0.0893 & -1.3682 & 0.2948 & $0^{*}$ \\
\hline $2 \mid 3$ & -0.0566 & 0.0880 & -0.6435 & 0.9449 & 0.5199 \\
\hline $3 \mid 4$ & 0.7248 & 0.0883 & 8.2059 & 2.0642 & $0^{*}$ \\
\hline $4 \mid 5$ & 2.7847 & 0.0983 & 2.8342 & 1.6194 & $0^{*}$ \\
\hline \multicolumn{6}{|l|}{ Independents } \\
\hline Class(2) & -0.2218 & 0.0589 & -3.7655 & 0.8011 & $0.0002^{*}$ \\
\hline Class(3) & -0.3643 & 0.0678 & -5.3729 & 0.6947 & $0^{*}$ \\
\hline Class(4) & -0.3090 & 0.0598 & -5.1702 & 0.7342 & $0^{*}$ \\
\hline Father edu. (c.e.) & 0.2467 & 0.0811 & 3.0413 & 1.2798 & $0.0024^{*}$ \\
\hline Father edu. (h.e.) & 0.4554 & 0.0936 & 4.8640 & 1.5769 & $0^{*}$ \\
\hline
\end{tabular}

Note. ${ }^{*} p<.05$, c.e.: compulsory educated, h.e.: high educated

Class and fathers' educational levels are statistically significant variables in this model. However, the status of the second university, faculty, and mothers' educational levels of the students are not significant. Therefore, the OLR model is constructed using only significant variables. Similarly, the OLR models for educational factors can be constructed as in Eq. (5-8). The odds ratio in Table 4 for the level of fathers' education (h.e.) is $\exp (0.4554)=1.5769$. In other words, students whose fathers' educational levels were of a higher degree supported the contribution of distance education on students' professions 1.57 times more than students whose fathers' educational levels were compulsory degrees.

The predicted probabilities of the model for educational factors are shown in Table 5 to interpret the model.

Table 5. Predicted probabilities of the OLR model for educational factors

\begin{tabular}{llllllc}
\hline & & \multicolumn{5}{c}{ Contribution Level } \\
\hline Father's education level & Class & 1 & 2 & 3 & 4 & 5 \\
\hline Non-literate & 1 & .228 & .258 & .188 & .268 & .058 \\
& 2 & .269 & .272 & .179 & .232 & .047 \\
& 3 & .298 & .278 & .172 & .211 & .041 \\
& 4 & .287 & .276 & .175 & .219 & .043 \\
\hline Compulsory degree & 1 & .187 & .238 & .193 & .309 & .073 \\
& 2 & .223 & .256 & .189 & .272 & .060 \\
& 3 & .249 & .266 & .184 & .249 & .052 \\
& 4 & .239 & .263 & .186 & .258 & .055 \\
\hline Higher degree & 1 & .158 & .217 & .192 & .344 & .089 \\
& 2 & .189 & .239 & .192 & .307 & .072 \\
& 3 & .212 & .251 & .190 & .283 & .063 \\
\hline
\end{tabular}

Note. Contribution levels 1: strongly disagree, 2: disagree, 3: undecided, 4: agree, 5: strongly agree 
According to the probabilities given in Table 5, the contribution of distance education to preparation for the professions increases with an increase in the level of the father's education. In addition, the idea that this contribution decreases in upper classes increases.

Working status, income and socio-economic levels of the students are economic factors which are considered as an OLR model for economic factors which can be easily constructed using the coefficients in Table 6 . All of the variables given in the table are found to be statistically significant.

Table 6. Outputs of the OLR model of economic factors

\begin{tabular}{lcccrr}
\hline Variables & $\hat{\beta}$ & std. error & t value & odds ratio & $p$-value \\
\hline Dependent & & & & & \\
\hline $1 \mid 2$ & -0.2214 & 0.0630 & -3.5169 & 0.8014 & $0.0004^{*}$ \\
$2 \mid 3$ & 0.9893 & 0.0637 & 1.5535 & 2.6895 & $0^{*}$ \\
$3 \mid 4$ & 1.7528 & 0.0648 & 2.7052 & 5.7709 & $0^{*}$ \\
$4 \mid 5$ & 3.7995 & 0.0739 & 5.1428 & 4.4681 & $0^{*}$ \\
\hline Independents & & & & & \\
\hline Income(501-1000 TL) & 0.1592 & 0.0557 & 2.8571 & 1.1725 & $0.0043^{*}$ \\
Income(1001- 1500 TL) & 0.1806 & 0.0553 & 3.2645 & 1.1980 & $0.0011^{*}$ \\
Income(1501- 2000 TL) & 0.2931 & 0.0608 & 4.8195 & 1.3405 & $0^{*}$ \\
Income(2001 TL and more) & 0.3206 & 0.0571 & 5.6130 & 1.3779 & $0^{*}$ \\
Socioeconomic level(bad) & 0.6618 & 0.0683 & 9.6884 & 1.9382 & $0^{*}$ \\
Socioeconomic level(moderate) & 0.9173 & 0.0637 & 1.4408 & 2.5025 & $0^{*}$ \\
Socioeconomic level(good) & 1.0734 & 0.0737 & 1.4564 & 2.9253 & $0^{*}$ \\
Socioeconomic level(very good) & 0.7395 & 0.0972 & 7.6074 & 2.0949 & $0^{*}$ \\
Working status(yes) & -0.1470 & 0.0373 & -3.9447 & 0.8633 & $0.0001^{*}$ \\
\hline
\end{tabular}

Note. ${ }^{*} p<.05$

Here, the students with good economic conditions stated that the contribution of distance education on students' professions was 2.92 times more than for other students.

The predicted probabilities of the model for economic factors are shown in Table 7 to interpret the model.

Table 7. Predicted probabilities of the OLR model for economic factors

\begin{tabular}{|c|c|c|c|c|c|c|c|}
\hline \multirow[b]{2}{*}{ Working status } & \multirow[b]{2}{*}{ Income } & \multirow[b]{2}{*}{ Socioeconomic level } & \multicolumn{5}{|c|}{ Contribution Level } \\
\hline & & & 1 & 2 & 3 & 4 & 5 \\
\hline \multirow[t]{15}{*}{ Yes } & $1-500 \mathrm{TL}$ & Very bad & .445 & .284 & .123 & .126 & .022 \\
\hline & & Bad & .293 & .289 & .167 & .210 & .042 \\
\hline & & Moderate & .243 & .275 & .180 & .249 & .053 \\
\hline & & Good & .215 & .264 & .185 & .275 & .061 \\
\hline & & Very good & .277 & .285 & .172 & .222 & .045 \\
\hline & 501-1000 TL & Very bad & .382 & .293 & .142 & .155 & .028 \\
\hline & & Bad & .242 & .275 & .180 & .250 & .053 \\
\hline & & Moderate & .198 & .255 & .187 & .292 & .068 \\
\hline & & Good & .174 & .240 & .189 & .318 & .078 \\
\hline & & Very good & .228 & .270 & .182 & .263 & .057 \\
\hline & $1001-1500 \mathrm{TL}$ & Very bad & .401 & .291 & .136 & .146 & .026 \\
\hline & & Bad & .257 & .280 & .176 & .238 & .049 \\
\hline & & Moderate & .211 & .262 & .185 & .279 & .063 \\
\hline & & Good & .186 & .248 & .188 & .305 & .073 \\
\hline & & Very good & .242 & .275 & .180 & .250 & .053 \\
\hline
\end{tabular}




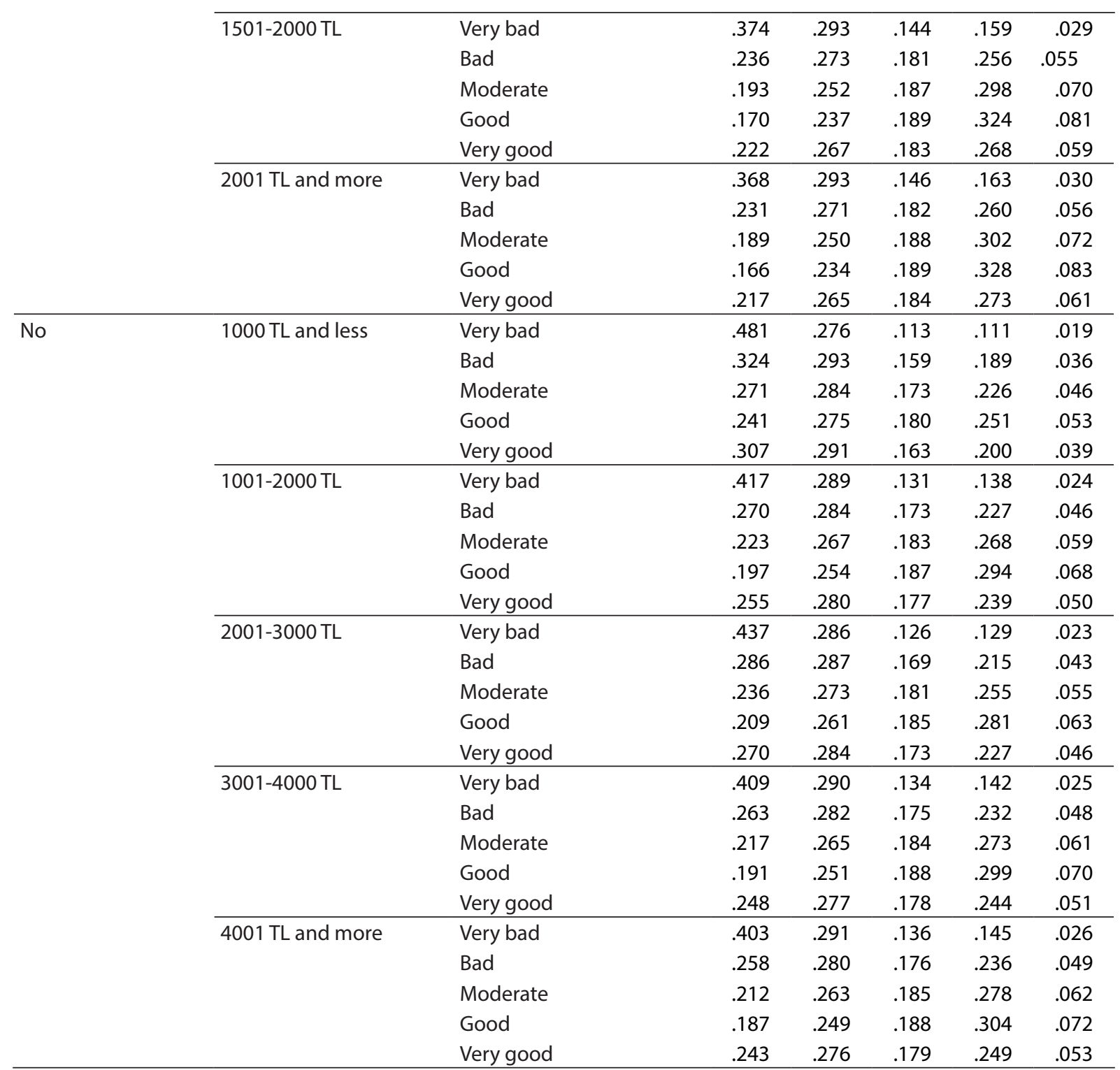

Note. Contribution levels 1: strongly disagree, 2: disagree, 3: undecided, 4: agree, 5: strongly agree

According to the results shown in Table 7 , the contribution of distance education in preparation for the professions is higher than for students who do not work in any job. An increase in income level and socioeconomic level also positively affects the thoughts of students. As a result, the students who stated that the contribution level was highest were students who did not work in any job and who had high income and socio-economic levels. Those who stated that the contribution was lowest were workers on low incomes from poor socio-economic levels.

\section{DISCUSSIONS AND CONCLUSION}

A questionnaire was conducted on a sample of approximately 17,000 students of the Faculty of Open Education, Faculty of Economics and Faculty of Business Administration at Anadolu University. The contribution level of distance education to preparation for the professions was modelled by three ordinal logistic regression tests using demographic, educational and economic factors. Predicted probabilities of each model were interpreted to show the effect of these factors. In addition, the results were compared with previous studies from the literature. 
Certain studies investigated the relationship between family size and/or family structure and educational attainment. For instance, Maralani (2008) suggests that for Indonesia, no consistent positive or negative relationship exists between family size and children's educational attainment. According to the results, despite the fact that the relationship between two variables had not reached a significant level in rural areas for the considered time period, the same relationship appeared to have changed from positive to negative for urban areas during the same period. A number of studies suggest either no relationship or an inconsistent relationship, such as those conducted by Dayioglu et al. (2009), Fitzsimons and Malde (2014), and Sandberg and Rafail (2014). A few researchers found a negative relationship between family size and educational attainment. These include Baez (2008), Rosenzweig and Zhang (2009), Bagger et al. (2013), Dumas and Lefranc (2013), Bougma et al. (2015) and Kugler and Kumar (2015). Blaabæk et al. (2017) adopted a different approach and argue that from a causality centered point of view, previous research studies that had found a negative relationship between family size and educational attainment were invalid. In addition to these studies, our results show that there is a positive relationship between family size and the contribution level of distance education to prepare students for the professions. A student, living in a more crowded family, thinks more positively than others about the contribution of distance education, as shown in Table 3.

Dumas and Lambert (2005) found that the education levels of fathers rather than mothers had an effect on the educational demands of individuals. Handa et al. (2004) show that the education of the father in a household is one of the main determinants of the education demands of an individual. In this study, it was concluded that the education level of the father had an effect on the education demands of other family members. The study examines the effect of parents' educational levels, wealth, gender, rural region, and numbers in households on education demand. Tansel (1997) suggests that maternal and paternal education are both effective on individuals' education, especially for individuals older than 15 years, using data from Ghana and the Ivory Coast. Another study suggesting that the educational level of the father is decisive with regard to demand for education is the work of Haan and Plug (2006). The results in our study show that the educational level of the father has a significant effect, while the educational level of the mother is not found to be significant in the OLR model. In addition, the contribution of distance education regarding preparation for the professions increases with the level of the father's education.

Holmes (1999) investigated the demand for education in terms of income, rather than the education of parents, using the Pakistan Integrated Household Surveys. Gurler et al. (2007) concludes that there is a direct relationship between the position of individuals and their household incomes. Accordingly, individuals with household incomes of individuals living in urban areas with a high demand for education in Turkey are higher than others.

The novelty of our study is that the socio-economic level of students is considered to be an explanatory variable. As a consequence, students whose socio-economic levels are moderate and good state that the contribution level of distance education is higher than for other students.

Authors' Note: This study is supported by the Anadolu University Scientific Research Projects Commission under grant No. 1601E034. 


\section{BIODATA and CONTACT ADDRESSES of AUTHORS}

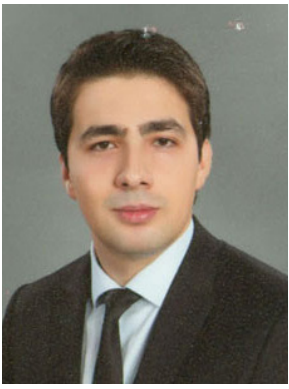

Dr. Mustafa CAVUS is a Research Assistant of Faculty of Science, Eskisehir Technical University. Dr. Cavus gained his Ph.D. in Applied Statistics at November, 2020. His academic interest areas are Design of Experiment, Statistical Machine Learning, Explainable Artificial Intelligence and Robust Statistics. He has 8 journal articles published in international indexes, 1 international book chapters and other national and international articles, papers submitted to international meetings.

Mustafa CAVUS

Department of Statistics, Faculty of Science

Address: Eskisehir Technical University, 26555, Eskisehir, Turkey

Phone: +90 22232135 50,

E-mail: mustafacavus@eskisehir.edu.tr

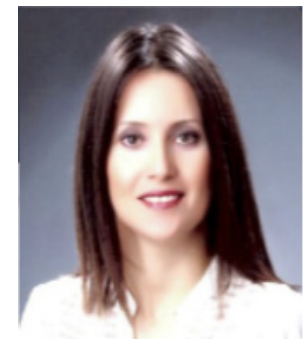

Dr. Betul KAN KILINC is an Prof. in Faculty of Science, Eskisehir Technical University. Dr. Kan Kilinc, gained her Ph.D. in Statistics at December, 2010. Her academic interest areas are data science, supervised-unsupervised learning algorithms, data mining, nonparametric regression, multivariate statistics, open and distance learning and $\mathrm{R}$ statistical programming. She has over than 20 journal articles published in international/national indexes, 2 international book chapters, and other international/national proceedings submitted to international meetings.

\section{Betul KAN KILINC}

Department of Statistics, Faculty of Science

Address: Eskisehir Technical University, 26555, Eskisehir, Turkey

Phone: +90 22232135 50,

E-mail: bkan@eskisehir.edu.tr

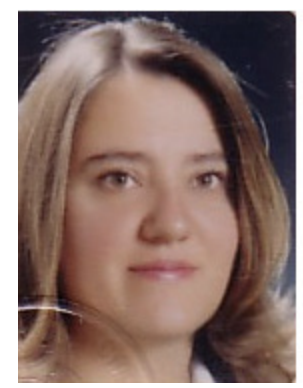

Dr. Berna YAZICI is a Professor of Statistics in Faculty of Science, Eskisehir Technical University. Dr. YAZICI got her Ph.D. from Statistics in 2001 and became Professor in 2013. She studies and gives the courses on Design of Experiments, Regression Analysis, Statistics. She has more than 40 papers in international indexes, 2 international, 1 national book chapters and more than 50 proceeding papers. She currently works for Eskisehir Technical University, Department of Statistics.

\section{Berna YAZICI}

Department of Statistics, Faculty of Science

Address: Eskisehir Technical University, 26555, Eskisehir, Turkey

Phone: +90 22232135 50,

E-mail: bbaloglu@eskisehir.edu.tr 


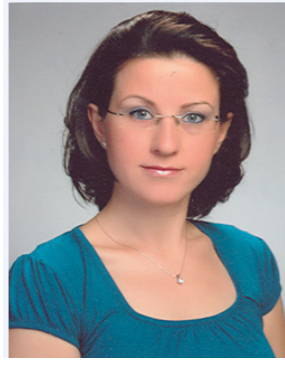

Dr. Seda TEKELI is an Associate Professor of Faculty of Labor Economics, Anadolu University. Dr. Tekeli gained her Ph.D. in Economics at 2010. Her academic interest areas are macroeconomics, economic development, growth, poverty, women empowerment, open and distance learning, the effect of distance education on development. She has over than 15 journal articles published in international indexes, 5 international book chapters and other national and international articles, papers submitted to international meetings.

\section{Seda TEKELI}

Department of Labor Economics and Industrial Relations, Faculty of Economy

Address: Anadolu University, 26470, Eskisehir, Turkey

Phone: +90 2223350580 ,

E-mail: sakyalcin@anadolu.edu.tr

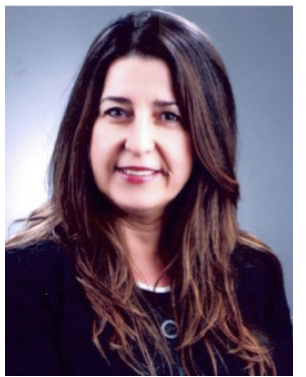

Dr. Guler GUNSOY is a Professor of Economy at Economy Faculty, Anadolu University. Dr. Gunsoy gained her Ph.D. in Economy at September, 1999. Her academic interest areas are macroeconomics, economic development, growth, poverty, women empowerment, open and distance learning, the effect of distance education on development. She has over than 10 journal articles published in international indexes, 3 national books, 5 national book chapters and other national and international articles, papers submitted to international meetings.

\section{Guler GUNSOY}

Department of Economics, Faculty of Economics

Address: Anadolu University, 26470, Eskisehir, Turkey

Phone: +90 222335 0580,

E-mail: gcinier@anadolu.edu.tr

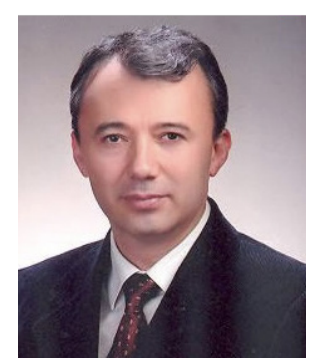

Dr. Bulent GUNSOY is a Professor of Economy at Faculty of Economics. He completed his Ph.D. in Economics at June, 1997. His academic interest areas are microeconomics, macroeconomics, globalization, structural reforms, development economics, open and distance learning. He has 12 journal articles published in international indexes, 6 national books, 9 national book chapters and other national and international articles, papers submitted to international congress.

\footnotetext{
Bulent GUNSOY

Department of Economics, Faculty of Economics

Address: Anadolu University, 26470, Eskisehir, Turkey

Phone: +90 222335 0580,

E-mail: bgunsoy@anadolu.edu.tr
} 


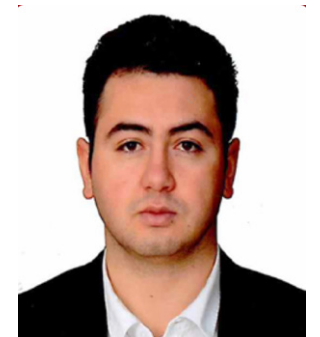

Dr. Caglar KARADUMAN is a research assistant at Faculty of Economics, Anadolu University. Dr. Karaduman gained his Ph.D. in Economics in April, 2018. His academic interest areas are macroeconomic productivity, technology diffusion, economic growth and development and macroeconomic performance. Karaduman has an interest also in the field of open and distance education from the perspective of economics. He has over than 10 journal articles published in international indexes, 1 book chapter and papers submitted to international meetings.

\section{Caglar KARADUMAN}

Department of Economics, Faculty of Economics

Address: Anadolu University, 26470, Eskisehir, Turkey

Phone: +90 222335 0580, 2564-5870,

E-mail: caglarkaraduman@anadolu.edu.tr

\section{REFERENCES}

Allmendiger, J. (1989). Educational systems and labor market outcomes. European Sociological Review, 5(3), 231-250. Retrieved from https://www.jstor.org/stable/pdf/522338. pdf?refreqid=excelsior\%3A08741828201010 760f17550232ee988c

Baez, J. E. (2008). Does more mean better? sibling sex composition and the link between family size and children's quality. IZA Discussion Paper Series, No. 3472. Retrieved January 21, 2019 from http:// ftp.iza.org/dp3472.pdf

Bagger, J., Birchenall, J. A., Mansour, H., \& Urzúa, S. (2013). Education, birth order, and family size. IZA Discussion Paper Series, No. 7454. Retrieved January 21, 2019 from http://ftp.iza.org/dp7454. pdf

Blaabæk, E. H., Jæger, M. M., Molitoris, J. (2017). Family size and children's educational attainment: identification from the extended family. Population Association of America Annual Meeting. 2017. Retrieved from https://paa.confex.com/paa/2017/mediafile/ExtendedAbstract/Paper12491/PAA_ Blaab aek_Jaeger_Molitoris.pdf

Boccanfuso, D., Larouche, A., \& Trandafir, M. (2015). Quality of higher education and the labor market in developing countries: evidence from an education reform in Senegal. World Development, 74(1), 412-424. doi.org/10.1016/j.worlddev.2015.05.007.

Bougma, M., LeGrand, T. K., \& Kobiané, J. F. (2015). Fertility decline and child schooling in urban settings of Burkina Faso. Demography, 52(1), 281-313. doi: 10.1007/s13524- 014-0355-0.

Clark, A. E., Frijters, P. \& Shields M. A. (2006). Income and happiness: Evidence, explanations and economic implications, Paris-Jourdan Sciences Economiques, Working Paper No: 2006-24, 1-35. Retrieved from https://halshs.archives-ouvertes.fr/halshs-00590436

Dayiouglu, M., Kirdar, M. G., \& Tansel, A. (2009). Impact of sibship size, birth order and sex composition on school enrolment in urban Turkey. Oxford Bulletin of Economics and Statistics, 71(3), 399426. doi.org/10.1111/j.1468-0084.2008.00540.

Dumas, C. \& Lambert, S. (2005). Patterns of intergenerational transmission of education: the case of Senegal. Retrieved 21 January from http://cep.lse.ac.uk/seminarpapers/28-03-06-DUM.pdf

Dumas, C., \& LeFranc, A. (2013). Sex in marriage is a divine gift: for whom? evidence from the manila contraceptive ban. IZA Discussion Paper, No. 7503. Retrieved January 21, 2019 from http://ftp. iza.org/dp7503.pdf

Fitzsimons, E., \& Malde, B. (2014). Empirically probing the quantity-quality model. Journal of Population Economics, 27, 33-68. doi.org/10.1007/s00148-013-0474-8. 
Haan, M. \& Plug, E. (2006). Estimates of the effect of parents' schooling on children's schooling using censored and uncensored samples. IZA Discussion Paper, No. 2416. Retrieved January 21, 2019 from http://ftp.iza.org/dp2416.pdf

Handa, S., Simler, R. K. \& Harrover, S. (2004). Human capital, household welfare, and children's schooling in Mozambique. International Food Policy Research Institue Research Report, No. 134. Retrieved January 21, 2019 from

https://ageconsearch.umn.edu/bitstream/37896/2/rr134.pdf

Holmes, J. (1999). Measuring the determinants of school completion in Pakistan: analysis of censoring and selection bias. Yale University Center Discussion Paper, No. 794. Retrieved January 21, 2019 from https://pdfs.semanticscholar.org/9e42/f5d074d53b7beca4011cffe9261b71d92088.pdf

Jacobs, P. A. \& Newstead S.E. (2000). The nature and development of student motivation, British Journal of Educational Psychology, (70), 243-254. doi.org/10.1348/000709900158119.

Kugler, A. D., \& Kumar, S. (2015). Preference for boys, family size and educational attainment in India. Demography, 54(3), 835-859. doi.org/ 10.3386/w21138

Kuo. Y. C. Walker. A. E.. Belland. B. R. \& Schroder. K. E. E. (2013). A predictive study of student satisfaction in online education programs. The International Review of Research in Open and Distance Learning, 14(1), 17-39. doi.org/10.19173/irrodl.v14i1.1338

Maralani, V., (2008). The changing relationship between family size and educational attainment over the course of socioeconomic development: evidence from Indonesia. Demography, 45(3), 693-717. doi.org/10.1353/dem.0.0013

OECD. (2018). The future of education and skills, Education 2030, 1-23. Retrieved from https://www. oecd.org/education/2030/E2030\%20Position\%20Paper\%20(05.04.2018).pdf

Ozturk. O. (2018). A logistic regression analysis of factors affecting enrollment decisions of prospective students of distance education programs in Anadolu University. Turkish Online Journal of Distance Education, 20(1), 145-160. doi.org/ 10.17718/tojde.522459

Rosenzweig, M. R., \& Zhang, J. (2009). Do population control policies induce more human capital investment? twins, birth weight and China's "One-Child" policy. Review of Economic Studies Limited, 76, 1149-1174. Retrieved from https://www.jstor.org/stable/40247636

Sahin, I. \& Shelley, M. (2008). Considering students' perceptions: the distance education student satisfaction model. Educational Technology \& Society, 11(3), 216-223. Retrieved from https://lib.dr.iastate. edu/cgi/viewcontent.cgi?article $=1006 \&$ context=pols_pubs

Sandberg, J., \& Rafail, P. (2014). Family size, cognitive outcomes, and familial interaction in stable, twoparent families: United States, 1997-2002. Demography, 51(5), 1895-1931. doi.org/ 10.1007/ s13524-014-0331-8

Tansel, A. (1997). Schooling attainment, parental education and gender in Cote d'Ivoire and Ghana. Economic Development and Cultural Change, 45(4), 825-856. Retrieved from https://www.jstor. org/stable/10.1086/452309 